\title{
Habitat restoration of coniferous forests on glaciofluvial eskers - four-year results
}

\author{
Guntis Brūmelis ${ }^{1 *}$, Egita Zviedre1, Iluta Dauškane' , Agita Treimane1', Sandra Ikauniece², \\ Annija Grebeža ${ }^{1}$
}

\author{
${ }^{1}$ Faculty of Biology, University of Latvia, Jelgavas 1, Riga LV-1004, Latvia \\ ${ }^{2}$ Nature Conservation Agency, Baznīcas 7, Sigulda LV-2150, Latvia \\ ${ }^{\star}$ Corresponding author, E-mail: guntis.brumelis@lu.lv
}

\begin{abstract}
European countries have made committments to conservation of habitats of concern listed in Annex 1 of the European Council Directive 92/43/EEC (21 May 1992) on the conservation of natural habitats and of wild fauna and flora. Much of present area of forest habitats of concern has been degraded, as natural processes in forests are not compatable with the main goal in commercial forests on wood productivity. The present work was focused on the EU protected habitat 9060 "Coniferous forests on, or connected to, glaciofluvial eskers". The typical plant communities of this habitat are well lit under a sparse canopy and often contain rare and protected sun-loving plants. Within the LIFE project "National Conservation and Management Programme for Natura 2000 sites in Latvia", in winter 2013 2014 restoration of two pine stands on an esker system was conducted in the Razna National Park. The restoration attempted to create the natural structure of this habitat by reducing shading of target sun-loving plants by partial harvest of trees and creation of patches of exposed mineral soil. The aim of the present work was to assess the effects of restoration using a Before-After treatment experimental design. In general, management had minimal effect on restoration of the target plant community. Development of a new Pinus sylvestris cohort was initiated, which is expected to increase shading in the future. Further restoration of esker habitat should be employed only when the target sun-loving species are still present, as seed dispersal from neighbouring stands and establishment will likely not be successful. Also, creation of patches with exposed mineral soil requires more complete scarification by mechanical equipment or by burning.
\end{abstract}

Key words: boreal, light, partial harvest, sun-lit, scarification, vegetation.

Abbreviations: ISA, Indicator Species Analysis; MRPP, multiple response permutation procedure.

\section{Introduction}

Land-use change has been the main cause of loss of biological diversity globally (Millennium Ecosystem Assessment 2005). Most of the forest area in the temperate zone of Europe was cleared for agriculture and for exploitation of wood during the Holocene, and much of the remaining woodland is post-agricultural secondary forest (Kaplan et al. 2009). Forests in the boreal and temperate zones that have not been affected by human use practically no longer exist (Brang 2005). Forest area is larger (> 40\%) in the boreal forest zone of Europe (Forest Europe 2011). However, these are now mostly industrial forests aimed at high productivity, and they lack natural structures like coarse woody debris and canopy gaps of variable size that are needed as habitat for many specialist species (Brūmelis et al. 2011).

Much has been learned about the reasons for loss of biological diversity and on means of management to halt this process (Villard, Jonsson 2009), but global incentives to halt the decline have failed (Butchart et al. 2010). The Aichi targets of the Convention of Biological Diversity
(2010) aim for an increase of area of protected territories to $17 \%$ by 2020 , and that $15 \%$ of degraded habitat needs to be restored. These targets are based on evidence that many forest specialist species require at least 20 to $30 \%$ suitable habitat in a landscape for survival, which can be most efficiently acheived by focusing conservation efforts in aggregations of habitats, and not throughout the countryside (Hanski 2000).

Natural disturbances like fire, insect damage and wind at different scales create patches of different size and structures, which create large spatial heterogeneity (Kuuluvainen 2002; Shorohova et al. 2002). The focus of habitat restoration in the boreal zone is on emulation of natural disturbance (Long 2009; Kuuluvainen, Grenfell 2012). In Latvia, restoration of forest habitat has been conducted within several EU LIFE and other projects, but regular and thorough monitoring of the results of restoration, if conducted after end of the project periods, is generally not published in scientific journals. However, the knowledge gained by practitioners and others in habitat restoration in Latvia and other countries has been reviewed and used to prepare the Protected Habitat Conservation 
Guidelines for Latvia (Ikauniece 2017).

Most, if not all, of the future funding in Latvia on habitat restoration will be focused on protected habitats listed in Annex 1 of the European Council Directive 92/43/EEC (21 May 1992) on the conservation of natural habitats and of wild fauna and flora (Council Directive 1992).

The present work was focused on the protected EU habitat 9060 "Coniferous forests on, or connected to, glaciofluvial eskers". The main characteristic of this type is hills or ridges of glaciofluvial origin that run parallel to past glacial ice movement. The forests are on slopes with coarse sandy soils, and area more lit and open than in lowland forests, which creates habitat for sun-loving species, including rare species like Pulsatilla patens, Dracocephalum ruyschiana, and Onobrychia arenaria (Bambe 2013). Historically, the main disturbance that maintained an open canopy is considered to be fire (Ikauniece 2017). However, it needs to be noted that most fires in Europe in the Holocene have been human-caused rather than of natural origin (Wallenius 2011; Dietze et al. 2018;). The fire frequency in the past 100 years has dramatically decreased due to lack of utilization of fire for land management and fire supression. As a result, increased shading and build up of an organic layer by shrub and subcanopy layers of Picea abies (Prescott et al. 2000; Augusto et al. 2002) has caused degradation of the values of sun-lit open habitats (Similä, Junninen 2012). Possible restoration measures to reduce shading and remove the organic layer are controlled burning, cutting of shrubs and some trees, and raking and removal of the organic layer in patches (Ikauniece 2017).

The aim of the present work was to assess the effects of restoration of two esker pine forest stands by shrub and tree cutting, and also removal by raking of the organic layer in dry pine mixed forest on an esker system. This was done using a replicated Before-After treatment experimental design.

\section{Materials and methods}

\section{Study area}

The study was conducted in the Razna National Park, situated in eastern Latvia in the central part of the Latgale Upland (Fig. 1). The average annual temperature is $-7.5^{\circ} \mathrm{C}$ in January and $16.8^{\circ} \mathrm{C}$ in July (Rove 2009). Restoration was conducted on glaciofluvial eskers, which cross the national park area from northeast to southwest. Two stands (Stands 2 and 4) were selected for the restoration in the forest management unit 122 . The selected stands were on sandy slopes dominated by Pinus sylvestris with P. abies enetering the canopy.

\section{Field data}

In 2013, nine representative, permanent monitoring plots (each $10 \times 10 \mathrm{~m}$ ) were established in each of the two stands selected for the restoration. Plot location was marked by

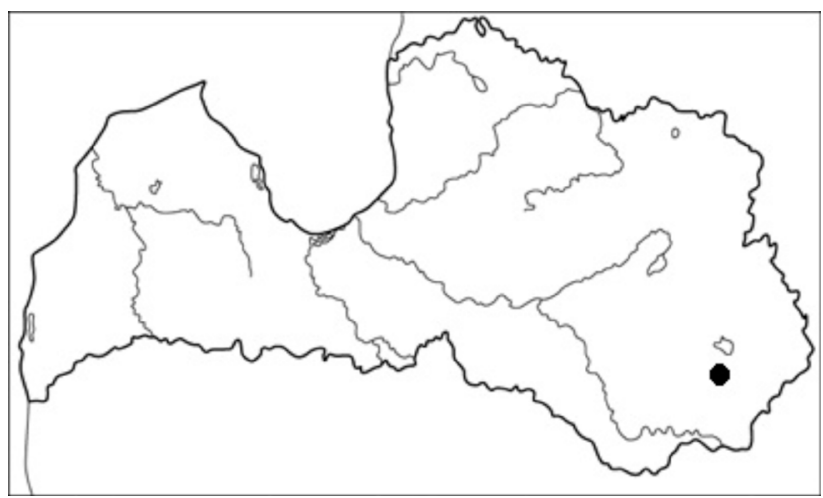

Fig. 1. Map showing location of the study area in Latvia.

permanent paint on a large P. sylvestris on the upper side of the plot on the slope, in the right corner of the plot (looking down the slope). Precise location of plot sides was checked from photographs of the plots taken when first established. Coordinates of plots are given in Table 1. The sampled area covered about $9 \%$ of each stand. Habitat restoration was conducted in winter 2013 - 2014 by cutting and removal of all $P$. abies in the canopy and understory. The trees were felled by chainsaw and wood and all branches were removed by forwarder. In addition, in autumn 2014 (after monitoring in that year), in the $100 \mathrm{~m}^{2}$ plots in Stand 4, the mineral soil was uncovered by removing the moss and soil $\mathrm{O}$-horizon layers by hand rake in patches. The mean area uncovered in plots was $11.8 \mathrm{~m}^{2}$ (range 0 to $20.2 \mathrm{~m}^{2}$ ); thus, about $10 \%$ of the stand area.

The vegetation was described in summer in 2013 (before cutting), 2014 (before raking conducted in that year), 2015

Table 1. Plot coordinates (LKS-92 geographic coordinate system) in the Razna National Park, Forest Management Unit 122

\begin{tabular}{|cccc|}
\hline Stand No. & Plot No & X coordinate & Y coordinate \\
\hline Stand 2 & 1 & 708220 & 6234674 \\
\hline & 2 & 708225 & 6234655 \\
& 3 & 708222 & 6234590 \\
\hline 4 & 708197 & 6234613 \\
\hline 5 & 708205 & 6234636 \\
\hline 6 & 708194 & 6234669 \\
\hline Stand 4 & 7 & 708183 & 6234676 \\
\hline & 8 & 708187 & 6234634 \\
\hline 9 & 708182 & 6234620 \\
\hline 1 & 708470 & 6234676 \\
\hline 2 & 708439 & 6234675 \\
\hline 3 & 708415 & 6234669 \\
\hline 4 & 708448 & 6234663 \\
\hline 5 & 708398 & 6234636 \\
\hline 6 & 708384 & 6234641 \\
\hline & 7 & 708414 & 6234629 \\
\hline & 9 & 708405 & 6234629 \\
\hline
\end{tabular}


and 2017. Percentage cover of all species (vascular plants and ground bryophytes) was determined. Plant species nomenclature followed Prieditis (2014) for vascular plants and Āboliņa et. al. (2015) for bryophytes. Diameter at 1.3 $\mathrm{m}$ height of all trees was measured in 2013 before cutting and 2014 after cutting. Counts were made of all established seedlings in each year of monitoring.

\section{Data analysis}

Differences on composition of plant communites was assessed by detrended correspondence analysis. Determination of significant differences in species cover and total cover of vegetation layers (canopy, subcanopy, herbs and moss) between years and stands was done using multiple response permutation procedure (MRPP) and indicator species analysis (ISA). These analyses were conducted using the program PC-ORD version 5.0. (McCune, Mefford 2006)

\section{Results}

\section{Total cover of vegetation layers}

MRPP analysis showed significant differences between years in cover of vegetation layers (canopy, subcanopy, herbs and moss) for Stand 4 and not Stand 2. In MRPP paired comparisons between years, in Stand 4 cover in layers in 2014 and 2015 significantly differed from that in 2013 and 2017 . Cover of the canopy did not significantly differ (ISA, $p>0.05$ ) between years, while the cover of the subcanopy layer was significantly lower (ISA, $p<0.05$ ) in the years after harvest in both stands, as expected after cutting. ISA showed significant differences $(p<0.05)$ between years in total moss cover (not herb layer cover), but only in Stand 4 , where the total cover of moss was less in 2014 (after cutting and before raking) and 2015 (after raking) than in 2013, but cover in 2013 and 2017 was similar (Fig. 2).

\section{Tree layers}

In Stand 2, the mean basal diameter of P. abies decreased from 19.1 to $6.6 \mathrm{~m}^{2} \mathrm{ha}^{-1}$ due to tree harvest, and in Stand 4 from 5.3 to $0.6 \mathrm{~m}^{2} \mathrm{ha}^{-1}$ (Table 2). Part of the P. abies and Betula pendula subcanopy was retained to prevent drastic change in light levels (Table 3). In Stand 4, almost all of the P. abies was cut. Aside from a few P. sylvestris trees in the 10.1 to $20.0 \mathrm{~cm}$ diameter class, all others were retained. The retained amount of deciduous tree species was very low.

After opening of the overstory canopy, abundant

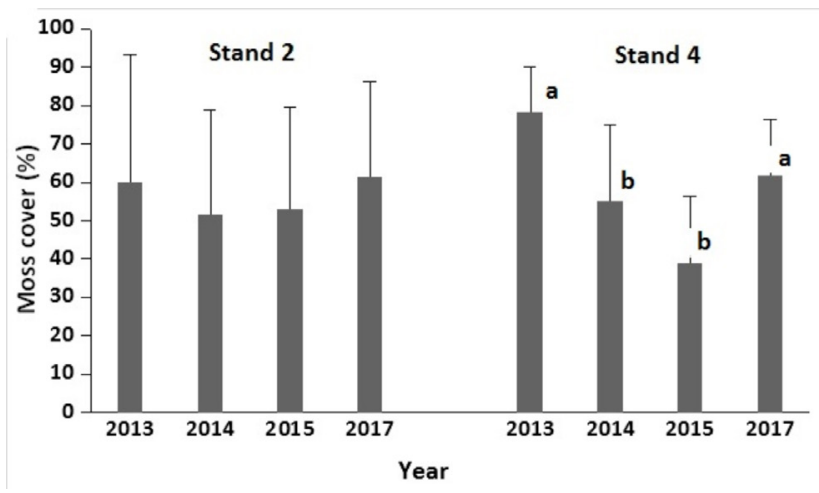

Fig. 2. Mean total moss cover in stands in the study period. Significant differences in vegetation layers (MRPP) are shown by different letters.

regeneration of all tree species occurred. Establishment of P. sylvestris was particularly high reaching 2667 seedlings in 2017 in Stand 4 where the moss and soil O-horizon layers and been removed in patches (Table 4 ).

\section{Changes in vegetation}

Detrended corresponse analysis (Fig. 3) of plant community data showed clusters of the two stands with considerable overlap. In addition, MRPP $(p<001)$ and ISA (Table 5) showed signifcant differences among the studied stands in composition of the plant communities. Among the moss species, Hylocomium splendens had greater cover in Stand 2, and Pleurozium schreberi and Ptilium crista-castrensis in Stand 4. The cover of Vaccinium vitis-idaea, Calluna vulgaris and Ptreridium aquilinum was higher in Stand 4, and Rubus saxatilis in Stand 2.

The only observed sun-loving species that were targets of the management were $P$. patens, a protected species found in one plot in Stand 2 before and after management, and Arctostaphylos uva-ursi in one plot in Stand 4 after management. Another protected species, Lycopodium annotinum, was found in two plots of Stand 4 before and after management.

After the employed management, there were some new species that appeared in $1-3$ plots of Stand 2. These were all common species of forest and/or open habitats, like Fragaria vesca, Melica nutans, Solidago virgaurea, Rumex acetosella and Seneceo jacobea. The only arriving species in Stand 4 were A. uva-ursi in one plot and Festuca ovina in three plots. Despite these changes, MRPP and ISA showed no significant differences in overall composition of plant

Table 2. Tree basal area $\left(\mathrm{m}^{2} \mathrm{ha}^{-1}\right)$ before and after cutting of subcanopy and saplings

\begin{tabular}{lcccccc} 
Stand No. & Time & Picea abies & Pinus sylvestris & Betula pendula & Populus tremula \\
Stand 2 & 2013 & 19.1 & 27.0 & 1.6 & 1.0 \\
\hline & 2014, after management & 6.6 & 25.0 & 1.6 & 1.1 \\
Stand 4 & 2013 & 5.3 & 42.1 & 1.0 & 0.00 \\
& 2014, after management & 0.6 & 41.2 & 1.0 & 0.00
\end{tabular}


Table 3. Average tree density (number ha- ${ }^{-1}$ ). Year 2013 represents the control time before cutting

\begin{tabular}{|c|c|c|c|c|c|c|c|c|c|}
\hline \multirow[t]{2}{*}{ Stand No. } & \multirow[t]{2}{*}{$\mathrm{DBB}(\mathrm{cm})$} & \multicolumn{4}{|c|}{2013} & \multicolumn{4}{|c|}{ 2014, after management } \\
\hline & & Picea abies & $\begin{array}{c}\text { Pinus } \\
\text { sylvestris }\end{array}$ & $\begin{array}{c}\text { Betula } \\
\text { pendula }\end{array}$ & $\begin{array}{l}\text { Populus } \\
\text { tremula }\end{array}$ & Picea abies & $\begin{array}{c}\text { Pinus } \\
\text { sylvestris }\end{array}$ & $\begin{array}{c}\text { Betula } \\
\text { pendula }\end{array}$ & $\begin{array}{l}\text { Populus } \\
\text { tremula }\end{array}$ \\
\hline \multirow[t]{6}{*}{ Stand 2} & $<5.1$ & 189 & 0 & 11 & 0 & 56 & 0 & 0 & 0 \\
\hline & $5.1-10$ & 133 & 0 & 0 & 0 & 0 & 0 & 0 & 0 \\
\hline & $10.1-20.0$ & 367 & 22 & 11 & 0 & 0 & 11 & 11 & 0 \\
\hline & $20.1-30.0$ & 144 & 33 & 11 & 0 & 56 & 33 & 11 & 0 \\
\hline & $30.1-40.0$ & 167 & 78 & 11 & 11 & 33 & 78 & 11 & 11 \\
\hline & $>40$ & 100 & 111 & 0 & 0 & 0 & 111 & 0 & 0 \\
\hline \multirow[t]{6}{*}{ Stand 4} & $<5.1$ & 456 & 0 & 33 & 0 & 0 & 0 & 22 & 0 \\
\hline & $5.1-10$ & 122 & 0 & 44 & 0 & 0 & 0 & 44 & 0 \\
\hline & $10.1-20.0$ & 189 & 56 & 67 & 0 & 0 & 33 & 67 & 0 \\
\hline & $20.1-30.0$ & 33 & 122 & 0 & 0 & 1 & 144 & 11 & 0 \\
\hline & $30.1-40.0$ & 0 & 256 & 0 & 0 & 0 & 222 & 0 & 0 \\
\hline & $>40$ & 0 & 67 & 0 & 0 & 0 & 78 & 0 & 0 \\
\hline
\end{tabular}

communities and for individual species between the times of plot monitoring, even in cover of any of the moss species after removal of patches of moss and the O horizon.

\section{Discussion}

Previous restoration attempts in habitat management in Finland by removal of shading trees and exposure of the mineral horizon have been successful in ensuring continuity of sunlit habitats and their respective plant communities (Similä, Junninen 2012). However, the employed habitat management in the present study by creating sun-lit conditions and partial removal of the ground layer with the soil $\mathrm{O}$ horizon did not achieve the goal of colonization of target sun-loving plant species. Rather, common plant species of open habitats colonized the stands. As exceptions regarding sun-loving species, the opening of the canopy might have improved conditions for the one $P$. patens individual that was found before management, and the newly arriving A. uva-ursi individual. Seeding experiments with $P$. patens have shown successful establishment after mechanical removal of the moss and O-horizon layers and particularly after controlled burning (Kalamees et al. 2005).
As appropriate conditions were created by restoration, the unsuccessful results can be partly explained by dispersal limitation. Target species like P. patens, D. ruyschiana, and $O$. arenaria were observed within forest stands, including in a clearcut, located near the managed sites at distances of a few $100 \mathrm{~m}$ to $1 \mathrm{~km}$. However, these distances were likely too far for successful dispersal and establishment.

Another reason for unsuccessful colonization of the target species might be rapid regrowth of the moss layer, as the total moss cover four years after management did not differ from that before management. The growth of $P$. schreberi from vegetative propagules on various exposed patches can be particularly rapid (Frego 1996), which would be expected to retard establishment in cases when seed germination did occur. The main factor limiting establishment of, for example P. patens, is formation of a thick litter and moss layer, rather than light conditions (Kalamees et al. 2005). It is likely that removal by raking of the past build-up of the $\mathrm{O}$ horizon by accumulation of $P$. abies litter (Prescott et al. 2000) was insufficient, and more complete scarification using heavy equipment or by burning would be required for a successful restoration outcome.

Table 4. Density of tree seedlings (number ha ${ }^{-1}$ ). Year 2013 represents the control time before cutting. The moss and organic layer was removed just after monitoring in 2014

\begin{tabular}{|c|c|c|c|c|c|}
\hline \multirow[t]{2}{*}{ Stand No. } & \multirow[t]{2}{*}{ Species } & \multicolumn{4}{|c|}{ Density of tree seedlings (number ha $\mathrm{h}^{-1}$ ) } \\
\hline & & 2013 & 2014 & 2015 & 2017 \\
\hline \multirow[t]{4}{*}{ Stand 2} & Picea abies & 0 & 0 & 78 & 89 \\
\hline & Pinus sylvestris & 0 & 0 & 444 & 1289 \\
\hline & Betula pendula & 0 & 0 & 200 & 378 \\
\hline & Populus tremula & 0 & 0 & 356 & 233 \\
\hline \multirow[t]{4}{*}{ Stand 4} & Picea abies & 0 & 0 & 178 & 211 \\
\hline & Pinus sylvestris & 0 & 0 & 689 & 2667 \\
\hline & Betula pendula & 0 & 0 & 189 & 111 \\
\hline & Populus tremula & 0 & 0 & 89 & 0 \\
\hline
\end{tabular}




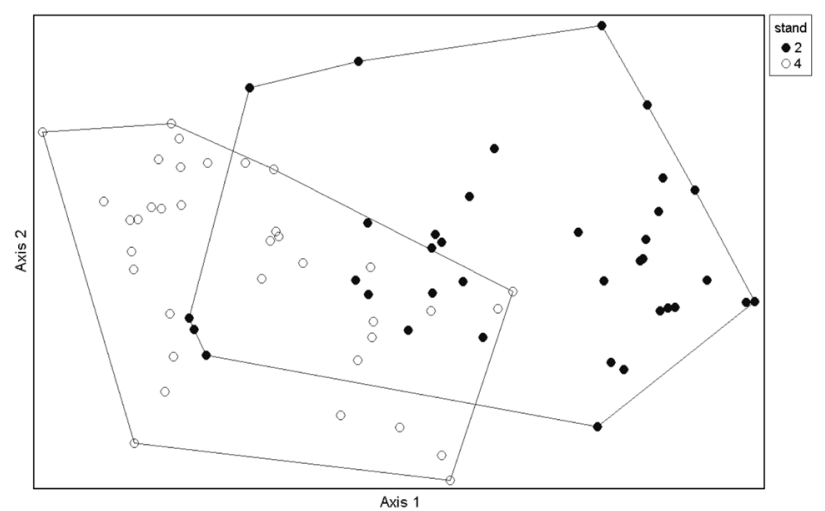

Fig. 3. Detrended correspondence ordination of plots. Stands are indicated.

A new cohort of $P$. sylvestris established in both stands, with greater density when the gorund layer was removed. Destruction of the vegetation cover (ericoid shrubs, feather moss) and availability of a seed source are required for successful establishment of $P$. sylvestris (Nilsson et al. 1996; Engelmark et al. 1998; Kuuluvainen, Juntunen, 1998). Thus, the formation of new shrub layer of a $P$. sylvestris with other tree species was not surprising, and will promote shading of the ground layer in the future. The created multi-cohort structure of $P$. sylvestris emulates that formed by natural distubances (Brūmelis et al. 2005), and in this respect the employed management can be considered to have been successful in improving the naturalness of the stands (Brūmelis et al. 2011). However, without formation of large gaps in the overstory P. sylvestris, which was not done in the restoration by cutting, after a period of slow growth further survival of this light-requiring tree in the understory is not expected (Gaudio et al. 2011).

Stand replication was not employed in the experimental design, as the study was restricted to the situation that was available in the restoration project. Also, the two stands in which the harvest was implemented appeared to initially differ. The cover of species like $V$. vitis-idaea and $C$. vulgaris, which require more open conditions, was higher in Stands 2. This limits comparison of the two treatments. In addition, there was no control treatment. However, we consider that the comparison of vegetation composition before and after the treatments does allow to offer some general recommendations regarding the restoration conducted. The study showed that efficient management of esker and other sunlit sites should be considered only when the target species are still present (Similä, Junninen 2012). More complete scarification of the O horizon is needed, and perhaps, artificial seeding needs to be implemented. The results can also be used in planning of restoration in other boreal habitats where cutting of the shrub layer is considered, albeit only regarding plant comminities and not other organism groups. It is important to report also lack of effects due to habitat management, as this information
Table 5. Indicator Species Analysis of plant communities in plots of studied stands. Only species with indicator values greater than 40 are shown

\begin{tabular}{lccc} 
Species & $\begin{array}{c}\text { Stand with } \\
\text { maximum } \\
\text { cover }\end{array}$ & $\begin{array}{c}\text { Indicator } \\
\text { value }\end{array}$ & p level \\
Calluna vulgaris & 4 & 41.3 & 0.019 \\
\hline Pleurozium schreberi & 4 & 66.2 & 0.0006 \\
\hline Hylocomium splendens & 2 & 67.2 & 0.0002 \\
\hline Rubus saxitilis & 2 & 67.9 & 0.0002 \\
Vaccinium vitis-idaea & 4 & 69.5 & 0.0002 \\
Ptilium crista- & 4 & 93 & 0.0002 \\
castrensis & & & \\
Pteridium aquilinum & 4 & 100 & 0.0002 \\
\hline
\end{tabular}

is required in planning management for conservation of biological diversity.

\section{Acknowledgements}

The study was supprted by the LIFE+ Project "National Conservation and Management Programme for Natura 2000 sites in Latvia" LIFE11 NAT/LV/000371 NAT-PROGRAMME, administered and implemented by the Nature Conservation Agency of Latvia. The support of the Latvian Dendroecologist Society is greatly appreciated.

\section{References}

Āboliņa A., Piterāns A., Bambe B. 2015. Lichens and bryophytes in Latvia. Checklist. Latvijas Valsts mežzinātnes institūts "Silava", DU AA “Saule”, Salaspils. /in Latvian/

Augusto L., Ranger B., Binkley D., Rothe A. 2002. Impact of several common tree species of European temperate forests on soil fertility. Ann. Forest Sci. 59: 233-253.

Bambe B. 2013. 9060 Coniferous forests on esker relif forms. In: Auniņš A. (ed) European Union Protected Habitats in Latvia. Identifcation Handbook. Second appended edition. Latvijas Dabas fonds, Vides aizsardzības un regionālās attīstības ministrija, Rīga, pp. 278-282. /in Latvian/

Brang P. 2005. Virgin forests as a knowledge source for central European silviculture: reality or myth? Forest Snow Landsc. Res. 79: 19-32.

Brumelis G., Elferts D., Liepina L., Luce I., Tabors G., Tjarve D. 2005. Age and spatial structure of natural Pinus sylvestris stands in Latvia. Scand. J. Forest Res. 20: 471-480.

Brumelis G., Jonsson B.G., Kouki J., Kuuluvainen T., Shorohova E. 2011. Forest naturalness in northern Europe: perspectives on processes, structures and species diversity. Silva Fenn. 45: 807-821

Butchart S.H., Walpole M., Collen B., van Strien A., Scharlemann J.P., Almond R.E., Baillie J.E., Bomhard B., Brown C., Bruno J., Carpenter KE., Carr GM., Chanson J., Chenery A.M., Csirke J., Davidson N.C., Dentener F., Foster M., Galli A., Galloway J.N., Genovesi P., Gregory R.D., Hockings M., Kapos V., Lamarque J.F., Leverington F., Loh J., McGeoch M.A., McRae L., Minasyan A., Hernández Morcillo M., Oldfield T.E., Pauly D., Quader S., Revenga C., Sauer J.R., Skolnik B., Spear D., 
Stanwell-Smith D., Stuart S.N., Symes A., Tierney M., Tyrrell T.D., Vié J.C., Watson R. 2010. Global biodiversity: Indicators of recent declines. Science 328: 1164-1168.

Convention of Biological Diversity. 2010. Strategic Plan 2011 2020. http://www.cbd.int/sp/targets/

Council Directive. 1992. Council Directive 92 /43 /EEC of 21 May 1992 on the conservation of natural habitats and of wild fauna and flora. Official Journal of the European Communities No I. 206/7.

Dietze E., Theuerkauf M., Bloom K., Brauer A., Dörfler W., Fesser I., Feurdean A., Gedminienė L., Giesecke T., Jahns S., KarpińskaKołaczek M., Kołaczek P., Lamentowicz M., Latałowa M., Marcisz K., Obremska M., Pędziszewska A., Poska A., Rehfeld K., Stančikaitė M., Stivrins N., Święta-Musznicka J., Szal M., Vassiljev J., Veski S., Wacnik A., Weisbrodt D., Wiethold J., Vannière B., Słowiński M. 2018. Holocene fire activity during low-natural flammability periods reveals scaledependent cultural human-fire relationships in Europe. Quat. Sci. Rev. 201: 44-56.

Engelmark O., Hofgaard A., Arnborg T. 1998. Successional trends 219 years after fire in an old Pinus sylvestris stand in northern Sweden. J. Veg. Sci. 9: 583-592.

Forest Europe. 2015. State of Europe's Forests 2015. https://www. foresteurope.org/docs/fullsoef2015.pdf

Frego K.A. 1996. Regeneration of four boreal bryophytes: colonization of experimental gaps by naturally occurring propagules. Can. J. Bot. 74: 1937-1942.

Gaudio N., Balandier P., Perret S., Ginisty C. 2011. Growth of understorey Scots pine (Pinus sylvestris L.) saplings in response to light in mixed temperate forest. Forestry 84: 187195.

Hanski I. 2000. Extinction debt and species credit in boreal forests: modelling the consequences of different approaches to biodiversity conservation. Ann. Zool. Fenn. 37: 271-280

Ikauniece S. (ed). 2017. Protected Habitat Management Guidelines for Latvia. Volume 6: Forests. Nature Conservation Agency, Sigulda.

Kalamees R., Püssa K., Vanha-Majamaa I., Zobel K. 2005. The effects of fire and stand age on seedling establishment of Pulsatilla patens in a pine-dominated boreal forest. Can. J. Bot. 83: 688-693.

Kaplan J.O., Krumhardt K.M., Zimmermann N. 2009. The prehistoric and preindustrial deforestation of Europe. Quat. Sci. Rev. 28: 3016-3034.

Kuuluvainen T. 2002. Natural variability of forests as a reference for restoring and managing biological diversity in boreal Fennoscandia. Silva Fenn. 36: 97-125.

Kuuluvainen T., Juntunen P. 1998. Seedling establishment in relation to microhabitat variation in a windthrow gap in a boreal Pinus sylvestris forest. J. Veg. Sci. 9: 551-562.

Kuuluvainen, T., Grenfell, R. 2012. Natural disturbance emulation in boreal forest ecosystem management-theories, strategies, and a comparison with conventional even-aged management. Can. J. For. Res. 42: 1185-1203.

Long J.N. 2009. Emulating natural disturbance regimes as a basis for forest management: a North American view. For. Ecol. Manage. 257: 1868-1873.

McCune B., Mefford M.J. 2006. PC-ORD. Multivariate Analysis of Ecological Data. Version 5.10. MjM Software, Gleneden Beach, Oregon, U.S.A.

Millenium Ecosystem Assessment. 2005. Ecosystems and Human Well-being: Biodiversity Synthesis. World Resources Institute, Washington, DC.

Nilsson M.-C., Steijlen I., Zackrisson O. 1996. Time-restricted seed regeneration of Scots pine in sites dominated by feather moss after clear-cutting. Can. J. For. Res. 26: 945-953.

Prescott C.E., Maynard D.G., Laiho R., 2000. Humus in northern forests: friend or foe? For. Ecol. Manage. 133: 23-36.

Prieditis N. 2014. Plants of Latvia, Encyclopedia. Gandrs, 888 p. /in Latvian/

Rove I. 2009. Nature Protection Plan of the Razna National Park. Latvijas Dabas fonds. /in Latvian/

Shorohova E., Kneeshaw D., Kuuluvainen T., Gauthier S. 2011. Variability and dynamics of old-growth forests in the circumboreal zone: implications for conservation, restoration and management. Silva Fenn. 45: 785-806.

Similä M., Junninen K. 2012. Ecological Restoration and Management in Boreal Forests - Best Practices from Finland. Metsähallitus, Finland.

Villard M.-A., Jonsson B.G. 2009. Setting Conservation Targets for Managed Forest Landscapes. Cambridge University Press.

Wallenius T. 2011. Major decline in fires in coniferous forests reconstructing the phenomenon and seeking for the cause. Silva Fenn. 45: 139-155. 